\title{
Evaluation of Nutritional and Environmental Conditions for Phenol Degradation by a Lebanese strain of Candida tropicalis
}

\author{
Hiba Koubeissi*, Hoda Yusef and Hanafy Holail \\ Department of Biological and Environmental Sciences, Faculty of Science, \\ Beirut Arab University, Debbieh, Lebanon \\ *Corresponding author
}

\begin{abstract}
A B S T R A C T
Keywords

Phenol

biodegradation,

Bioremediation,

Candida tropicalis,

Phenol

measurement,

Plackett-Burman.

Article Info

Accepted:

24 January 2017

Available Online:

10 February 2017

Phenol is a toxic hydrocarbon for nervous system, kidneys, liver, muscles and immune system. It is also mutagenic and possibly carcinogenic. Phenol containing- pollutants are dangerous and spread worldwide in the industrial effluents. The present study aimed to isolate a potent microorganism able to degrade phenol, as well as to evaluate the nutritional and environmental conditions that lead to its maximum degradation. A yeast isolated from petroleum-contaminated soil on MSM supplemented with phenol as sole carbon source, was identified by $28 \mathrm{~S}$ rDNA sequencing. Residual phenol was estimated using 4-AAP method and the growth of yeast was measured spectrophotometrically at 600 $\mathrm{nm}$. Candida tropicalis $\mathrm{H}$ was found to be highly effective for the removal of phenol. Phenol degradation was approximately $92.89 \%$ of an initial concentration of $2000 \mathrm{mg}$ phenol $1^{-1}$ at $30^{\circ} \mathrm{C}$ in shaken culture $(100 \mathrm{rpm})$ after 3 days incubation. After the application of Plackett-Burman design, $99.91 \%$ degradation of phenol was achieved. The most effective factors influencing phenol degradation, among studied 11 variables, were $\mathrm{K}_{2} \mathrm{HPO}_{4}$ and culture volume. Candida tropicalis $\mathrm{H}$ could be a good candidate for the bioremediation of phenol contaminants in heavily polluted sites. A phytotoxicity study revealed that the biodegradation of phenol resulted in its detoxification, which indicated a possible use of phenol containing-effluents in the irrigation of plants after bioremediation process.
\end{abstract}

\section{Introduction}

The bio-control of pollutants resulted from the manufacture of many products such as pharmaceutical drugs, plastics, paints, detergents and others, has occupied an important interest in the scientific investigations in order to attenuate their high impact on the environment as well as on human health (Kulkarni and Kaware, 2013). Phenol is one of the dangerous pollutants spread worldwide in the environment (EPA, 2002). Its toxicity resides in the hydrophobicity of the compound and its ability to form free radicals (Hansh et al., 2000). This toxicity is translated not only by its effect on different body organs and systems like skin, nervous system, eyes, liver and kidneys (Sinha et al., 2011), blood components (Michalowicz and Duda, 2007), hormones (Jung et al., 2004 and Aoyama et al., 2005), mutations (Michalowicz and Duda, 2007), immunotoxicity (McCue et al., 2003 and Yao and Hou, 2004), lethality (EPA, 2002), but also by its effect on plants (Flocco et al., 2002 and Ucisk and Trapp, 2006). 
Howevver, the carcinogenicity of phenol is inadequate for an assessment of the potential for phenol to cause cancer in humans (EPA, 2002), biological processes are widely used to remove phenol from different polluted areas (Arutchelvan et al., 2006; Geng et al., 2006 and Christen et al., 2012), in addition to several physical and chemical remediation methods such as polymerization, photodecomposition, membrane based separation (Kulkarni and Kaware, 2013), electro coagulation (El-Ashtoukhy et al., 2006), extraction (Khanahmedzadeh et al., 2012), advanced oxidation processes (Saeed and Ilyas, 2012), adsorption and ion exchange method (Qadeer and Rehan, 2002 and Kulkarni and Kaware, 2013).

The non-biological processes have serious drawback like high cost and formation of hazardous byproducts, whereas the bioremediation furnishes economical and environmental advantages which make it the better approach for phenol removal (Banerjee and Ghoshal, 2010 and Christen et al., 2012). Many studies were done to screen for appropriate microorganisms that can tolerate the inhibitory effects of phenol and effectively degrade it at relatively high concentration (Jiang et al., 2007a, Liu et al., 2011 and Basak et al., 2013). In the present investigation, an efficient isolate of yeast was able to detoxify phenol-containing water.

\section{Materials and Methods}

\section{Phenol stock solution and culture medium}

Phenol stock solution of a concentration $50000 \mathrm{mg} / \mathrm{l}$ was prepared by dissolving $10 \mathrm{~g}$ of phenol into $200 \mathrm{ml}$ of sterile distilled water. The solution was then filter sterilized using bacterial filter $(0.2 \mu \mathrm{m}$ pore-size $)$ and stored in a sterilized dark bottle $(250 \mathrm{ml})$ (Liu et al., 2013). Ingredients of culture medium were all of analytical grade and obtained from Oxoid, Ldt. Mineral salt medium (MSM) contained (g/l) (Liu et al., 2013): $\mathrm{K}_{2} \mathrm{HPO}_{4}$, $0.4 ; \mathrm{KH}_{2} \mathrm{PO}_{4}, 0.4 ; \mathrm{NaCl}, 0.1 ; \mathrm{MgSO}_{4} .7 \mathrm{H}_{2} \mathrm{O}$, $0.2 ; \mathrm{MnSO}_{4} . \mathrm{H}_{2} \mathrm{O}, 0.01 ; \mathrm{Fe}_{2}\left(\mathrm{SO}_{4}\right)_{3} . \mathrm{H}_{2} \mathrm{O}, 0.01$; $\mathrm{Na}_{2} \mathrm{MoO}_{4} .2 \mathrm{H}_{2} \mathrm{O}, 0.01 ;\left(\mathrm{NH}_{4}\right)_{2} \mathrm{SO}_{4}$, 1. Final $\mathrm{pH}: 7 \pm 0.2$. For solid media, $15 \mathrm{~g}$ of agar/liter were added.

\section{Isolation and identification of a phenol- degrading microorganism}

Candida tropicalis $\mathrm{H}$ was isolated from petroleum-contaminated soil samples collected from different small local landfills in Beirut, Lebanon. Inocula were introduced into MSM supplemented with $1000 \mathrm{mg} / \mathrm{l}$ of phenol as sole carbon source. Shaken cultures (150 rpm) were incubated at $30{ }^{\circ} \mathrm{C}$ for a week. Transfers from liquid medium to solid medium allowed the separation of morphologically different isolates and further purification was done to obtain pure colonies. Isolates were tested to compare their phenoldegrading ability and detect the most potent strain. Fifty ml of MSM supplemented with $1000 \mathrm{mg} / \mathrm{l}$ phenol were dispensed in each 250 $\mathrm{ml}$ Erlenmeyer flasks, then inoculated with 5 $\%(\mathrm{v} / \mathrm{v})$ from seed culture (OD $600 \mathrm{~nm}=1)$. The fermentation process was conducted under shaken condition at $30{ }^{\circ} \mathrm{C}$ for 5 days. Seed culture was prepared by transferring inocula from a yeast slant (24 hrs old) into $250 \mathrm{ml}$ Erlenmeyer flasks containing $50 \mathrm{ml}$ MSM supplemented with $1 \mathrm{~g} / \mathrm{l}$ peptone (Tiwari and Mondal, 2015). The culture was grown aerobically by shaking $(150 \mathrm{rpm})$ at 30 ${ }^{\circ} \mathrm{C}$ for $18 \mathrm{hrs}$ until reached an absorbance equivalent to $1($ A $600 \mathrm{~nm}=1)$. A potent yeast isolate was selected and identified.

DNA was isolated according to the protocol of GeneJet genomic DNA purification kit (Thermo) number K0721. The yeast 28S rDNA was amplified from the total genomic DNA by using Maxima Hot Start PCR Master Mix (Thermo) number K1061 and by using universal specific primers designated to amplify $1500 \mathrm{bp}$ fragment of the $28 \mathrm{~S}$ rDNA 
regions. The primers were: NL 1 (5'GCATATCAATAAGCGGAGGAAAAG) and NL 4 (5' GGTCCGTGTTTCAAGACG $\mathrm{G})$. The PCR was carried out for 35 cycles, denaturation at $94{ }^{\circ} \mathrm{C}$ for $1 \mathrm{~min}$, annealing at $50{ }^{\circ} \mathrm{C}$ for $2 \mathrm{~min}$ and extension at $74{ }^{\circ} \mathrm{C}$ for 1.5 $\min$.

An initial 3 min denaturation at $94{ }^{\circ} \mathrm{C}$ and a final $5 \mathrm{~min}$ extension at $74{ }^{\circ} \mathrm{C}$ were applied. Then PCR clean up to the PCR product was conducted using GeneJET ${ }^{\mathrm{TM}}$ PCR Purification Kit (Thermo) number K0701. The sequences obtained were aligned with known 28S rDNA sequences in the Genbank database using the basic local alignment search tool (BLAST) at the National Center for Biotechnology Information

(http://www.ncbi.nlm.nih.gov/BLAST/) and percent homology scores were generated to identify the yeast isolate.

The phylogenetic tree was constructed with MEGA 3 (Molecular Evolutionary Genetics Analysis) 3 software.

\section{Quantitative determination of phenol}

The concentration of phenol in MSM was determined by 4-AAP method (Martin, 1949 and Neumann, 2004): After removing of yeast cells by centrifugation at $6000 \mathrm{rpm}$ for 20 min., the presence of phenol in the supernatant was revealed by the appearance of a pink color. The intensity of the pink color was measured using a spectrophotometer at $492 \mathrm{~nm}$. The concentration of phenol in the medium was calculated based on the standard curve previously drawn using different concentrations of phenol. The percentage of phenol degradation was calculated by the mean of the following formula:

(Initial phenol concentration - Residual phenol concentration)

Initial phenol concentration
Nutritional and environmental factors affecting growth and phenol degradation by Candida tropicalis $\mathbf{H}$

The effects of static and shaken conditions (100 and $150 \mathrm{rpm}$ ), incubation temperature (25, 30 and $35^{\circ} \mathrm{C}$ ), $\mathrm{pH}$ of culture medium $(6.0,6.5,7.0,7.5$ and 8$)$, incubation period (1, 2, 3, 4 and 5 days) and initial phenol concentration $(1000,1250,1500,1750,2000$ and $2250 \mathrm{mg} / \mathrm{l}$ ), known for their impact on the activity of phenol degradation mechanism of the microorganism, were investigated. For this purpose, fifty $\mathrm{ml}$ of autoclaved MSM were dispensed in Erlenmeyer flasks $250 \mathrm{ml}$, inoculated with $5 \%(\mathrm{v}: \mathrm{v})$ from seed culture (OD 600nm = 1), then fortified with adequate phenol concentration (filter-sterilized) and incubated under the tested conditions. The residual concentration of phenol in the medium was evaluated and the percentage of the degraded phenol was calculated. The growth of the isolate was determined spectrophotometrically, the absorbance was measured at $600 \mathrm{~nm}$ against a blank derived from uninoculated medium incubated under the same conditions.

Optimization of phenol degradation by Candida tropicalis $\mathbf{H}$. using multi-factorial statistical design: Plackett-Burman design

Plackett-Burman design was applied to reflect the relative importance of eleven various factors $\quad\left(\mathrm{K}_{2} \mathrm{HPO}_{4}, \quad \mathrm{KH}_{2} \mathrm{PO}_{4}, \quad \mathrm{NaCl}\right.$, $\mathrm{MgSO}_{4} \cdot \mathrm{H}_{2} \mathrm{O}, \mathrm{MnSO} 4 . \mathrm{H} 2 \mathrm{O}, \mathrm{Fe}_{2}\left(\mathrm{SO}_{4}\right)_{3} \cdot \mathrm{H}_{2} \mathrm{O}$, $\mathrm{Na}_{2} \mathrm{MoO}_{4} \cdot 2 \mathrm{H}_{2} \mathrm{O},\left(\mathrm{NH}_{4}\right)_{2} \mathrm{SO}_{4}, \mathrm{pH}$, inoculum size $(\%)$, and volume of culture medium (ml)) affecting the phenol degradation. MSM dispensed in $250 \mathrm{ml}$ Erlenmeyer flasks and supplemented with $2000 \mathrm{mg} / \mathrm{l}$ phenol, was incubated under shaken condition (100 rpm) at $30{ }^{\circ} \mathrm{C}$. At the end of the incubation time (3 days), the phenol measurement assay was done. All experimental conditions (trials) were performed in triplets. The main effect 
that was estimated as a difference between both averages of measurements made at high level $(+1)$ and the low level (-1) of each examined factor affecting phenol degradation, was determined using the following equation: $\mathrm{E}_{\mathrm{xi}}=\left(\Sigma \mathrm{M}_{\mathrm{i}+}-\Sigma \mathrm{M}_{\mathrm{i}-}\right) / \mathrm{N}$. Where $\mathrm{E}_{\mathrm{xi}}$ is the variable main effect, $\mathrm{M}_{\mathrm{i}_{+}}$and $\mathrm{M}_{\mathrm{i}_{-}}$are the percentages of phenol degradation in trials where the independent variable $\left(\mathrm{x}_{\mathrm{i}}\right)$ was present in high or low level, respectively, and $\mathrm{N}$ is the number of trials divided by two. A main effect figure with positive sign indicates that the high level of the investigated variable is nearer to optimum and a negative sign indicates that the low level of this variable is nearer to optimum. Using Microsoft Excel, statistical t-values for equal unpaired samples were calculated for determination of variable significance.

\section{Time course degradation of phenol under optimized conditions}

Time course degradation of phenol under optimized conditions was investigated to minimize the incubation period. The optimized MSM (75 ml/flask) was dispensed in $250 \mathrm{ml}$ Erlenmeyer flasks, supplemented with $2000 \mathrm{mg} / \mathrm{l}$ phenol and inoculated with 7 $\%(\mathrm{v} / \mathrm{v})$ from a seed culture $\left(\mathrm{OD}_{600 \mathrm{~nm}}=1\right)$, then incubated under shaken condition (100 $\mathrm{rpm})$ at $30{ }^{\circ} \mathrm{C}$. Analyses were performed at different time intervals (1, 2, 3 or 4 days).

\section{Phytotoxicity study}

The toxicity of degraded phenol (2000 mg/l) in the optimized MSM by Candida tropicalis $\mathrm{H}$ was evaluated. The phytotoxicity study was carried out at room temperature, five grains of Triticum aestivum (wheat) and five seeds of Lens culinaris (lentils) were planted in pots of the same size. For each plant, two pots of each set were cultivated; the first set was irrigated with MSM (control), the second set was irrigated with treated MSM (supplemented with $2000 \mathrm{mg} / \mathrm{l}$ of phenol, inoculated with $C$. tropicalis $\mathrm{H}$ and incubated under optimized conditions), the third set was irrigated with untreated MSM (supplemented with $2000 \mathrm{mg} / \mathrm{l}$ of phenol). After 7 days of germination, shoot and root lengths were measured. The seedlings were dried at $60{ }^{\circ} \mathrm{C}$ till constant dry weights were recorded.

\section{Results and Discussion}

\section{Isolation and identification of a phenol- degrading microorganism}

A yeast isolate that can thrive in MSM supplemented with $1000 \mathrm{mg} / \mathrm{l}$ phenol, was selected for optimization of phenol degradation. The phylogenetic analysis based on $28 \mathrm{~S}$ rRNA gene sequence showed $96 \%$ similarity of yeast isolate with various Candida genotypes and the phylogenetic tree was presented in figure 1. Based on these phylogenetic characterization results, the selected isolate was identified as member of the species Candida tropicalis and it was named Candida tropicalis $\mathrm{H}$. Many studies reported that isolated microorganisms from phenol polluted areas were adapted to phenol removal (Schie and Yong, 1998; Soudi and Kolahchi, 2011). In the present study, a yeast isolate showed a high potentiality to remove phenol from its culture medium.

Nutritional and environmental factors affecting growth and phenol degradation by Candida tropicalis $\mathbf{H}$

The investigation on the effect of nutritional and environmental factors on the efficiency of phenol degradation by Candida tropicalis $\mathrm{H}$ revealed that the optimal degradation (approximately $92.89 \%$ ) of an initial concentration of $2000 \mathrm{mg}$ phenol $\mathrm{l}^{-1}$ was obtained in culture incubated under shaken condition (100 rpm) at $30{ }^{\circ} \mathrm{C}$ for 3 days using MSM (pH 7.5) (Fig. 2, 3, 4 and Table 1). The 
moderate shaken condition $(100 \mathrm{rpm})$ within 3 days explored the moderate demand of oxygen level. Molecular oxygen is required as a co-substrate for the microbial degradation of wide variety of organic chemicals; including hydrocarbons and aromatic ring compounds (Basha et al., 2010). Our finding matches with that of Kuntiya et al. (2013) where the moderate shaking speed of 100-125 rpm was used for phenol degradation by Candida tropicalis no. 10.Numerous researches carried out similar experiments to investigate the effect of temperature and $\mathrm{pH}$ on phenol degradation by microorganisms (Kim and Armstrong, 1981; Robertson and Alexander, 1992; Pakula et al., 1999; Annadurai et al., 2002; Kuntiya et al., 2013 and Sivasubramania and Namasivayam, 2014). The increase of temperature from 28 ${ }^{\circ} \mathrm{C}$ to $30{ }^{\circ} \mathrm{C}$ improved the growth yield of $C$. tropicalis PHB5 and the biodegradation process (Basak et al., 2013). These findings are in coincidence with the results obtained in the current study, where the optimal temperature was $30{ }^{\circ} \mathrm{C}$. Decline in phenol degradation at higher temperature can be attributed to low biomass, cell decay or to the thermal deactivation of phenol degrading enzymes. In the current study, results showed that $\mathrm{pH} 7.5$ led to the better phenol degradation. Similar results for phenol degradation were observed with Candida tropicalis HP 15 (Krug and Straube, 1986). Phenol concentration above $2000 \mathrm{mg} / \mathrm{l}$ resulted in a great inhibition of cell growth and phenol degradation. The maximum tolerable phenol concentration that Candida tropicalis $\mathrm{H}$ can degrade efficiently was 2000 $\mathrm{mg} / \mathrm{l}$. These findings are in good agreement with those found by Jiang et al. (2007b), where Candida tropicalis was able to degrade up to $2000 \mathrm{mg} / \mathrm{l}$ of phenol. The toxicity threshold concentration of phenol against microbial strains is different from a strain to another. This toxicity resulting in cell decay can be attributed at the cellular level, according to Heipieper et al., 1994) to a feasible suggestion that phenolic compounds degrade the cell membrane integrity, reducing the membrane's efficacy as a selective. At the molecular level, dehydrogenase enzymes needed in catalyzing the biological oxidation of organic compounds, are membrane associated (Kewelo et al., 1990 and Heipieper et al., 1991 and 1992). Hence, the high concentration of phenol inhibits these enzymes leading to the decrease of degradation potential. The percentage of phenol degradation was also influenced by the incubation period; Candida tropicalis $\mathrm{H}$ degraded $25.67 \%$ of the initial phenol concentration $(2000 \mathrm{mg} / \mathrm{l})$ within $24 \mathrm{hrs}$, the percentage increased till $92.98 \%$ after 3 days. After 3 days, phenol degradation remained almost constant, which may be due to the saturation of active sites of utilizing enzymes (Supriya and Neehar, 2014). Also, Farag and Abd-Elnaby (2014) registered that Fenellia flavipes could consume $1500 \mathrm{mg} / \mathrm{l}$ of phenol during $72 \mathrm{hrs}$.

\section{Optimization of phenol degradation by Candida tropicalis $\mathbf{H}$. using multi-factorial statistical design: Plackett-Burman design}

Plackett-Burman design was applied to reflect the relative importance of eleven various factors (Tables 2 and 3). The modified and optimized culture medium containing $(\mathrm{g} / \mathrm{l})$ : $\mathrm{K}_{2} \mathrm{HPO}_{4}, \quad 0.6 ; \quad \mathrm{KH}_{2} \mathrm{PO}_{4}, 0.2 ; \mathrm{NaCl}, 0.15$; $\mathrm{MgSO}_{4} \cdot \mathrm{H}_{2} \mathrm{O}, \quad 0.3 ; \quad \mathrm{MnSO}_{4} \cdot \mathrm{H}_{2} \mathrm{O}, \quad 0.005$; $\mathrm{Fe}_{2}\left(\mathrm{SO}_{4}\right)_{3} \cdot \mathrm{H}_{2} \mathrm{O}, \quad 0.015 ; \quad \mathrm{Na}_{2} \mathrm{MoO}_{4} \cdot 2 \mathrm{H}_{2} \mathrm{O}$, 0.005; $\left(\mathrm{NH}_{4}\right)_{2} \mathrm{SO}_{4}, 0.5, \mathrm{pH}, 7$; and volume of culture medium, $75 \mathrm{ml} / 250 \mathrm{ml}$ flask, inoculated with $7 \%$ inoculum and incubated for 3 days at $30^{\circ} \mathrm{C}$ under shaken condition at $100 \mathrm{rpm}$, showed phenol degradation $99.91 \%$ which was greater than that recorded in the basal medium that showed $92.89 \%$. The main effect was calculated and presented graphically (Fig. 5). Statistical analysis of the data is demonstrated in table 4 as t-value for 
the eleven experimental variables. The significance level was determined using the ttest. The factors which showed a high confidence percentage were $\mathrm{K}_{2} \mathrm{HPO}_{4}$ and volume of the culture medium, showing that they were the most positive significant variables affecting phenol degradation by $C$. tropicalis $\mathrm{H}$ (Fig. 6). Plackett-Burman design, applied in the current investigation, showed a great efficiency in the optimization of phenol degradation by Candida tropicalis $\mathrm{H}$. The results demonstrated that the percentage of degradation was enhanced in one of the trials to $99.91 \%$. Culture volume with positive level was found to have an enhancement effect on phenol degradation by Candida tropicalis $\mathrm{H}$, this finding is in agreement with that found by Kuntiya et al. (2013). In addition, the increase in the concentration of di-potassium hydrogen phosphate $\left(\mathrm{K}_{2} \mathrm{HPO}_{4}\right)$ had a remarkable positive effect; this coincides with the results achieved in the study of Ghanem et al. (2009). Also, the high level of $\mathrm{NaCl}, \quad \mathrm{MgSO}_{4} \cdot \mathrm{H}_{2} \mathrm{O}$ and $\mathrm{Fe}_{2}\left(\mathrm{SO}_{4}\right)_{3} \cdot \mathrm{H}_{2} \mathrm{O}$ (as obtained by Ghanem et al. (2009)) and the high level of $\mathrm{KH}_{2} \mathrm{PO}_{4}$ (as reported by Panidmadevi et al. (2014)), had positive effects on phenol degradation by $C$. tropicalis $\mathrm{H}$. On the other hand, the high levels of $\mathrm{MnSO}_{4} \cdot \mathrm{H}_{2} \mathrm{O}, \mathrm{Na}_{2} \mathrm{MoO}_{4} \cdot \mathrm{H}_{2} \mathrm{O}$, and $\left(\mathrm{NH}_{4}\right)_{2} \mathrm{SO}_{4}$ had negative effects on phenol degradation by $C$. tropicalis $\mathrm{H}$ contrarily to Ghanem et al. (2009), MnSO4.H2O and $\mathrm{NaMoO}_{4} \cdot 2 \mathrm{H}_{2} \mathrm{O}$ had a negative effect on phenol degradation by $C$. tropicalis $\mathrm{H}$.

Table.1 Effect of $\mathrm{pH}$ on growth and phenol degradation by Candida tropicalis $\mathrm{H}$

\begin{tabular}{ccc}
\hline pH & $\begin{array}{c}\text { Phenol } \\
\text { degradation }(\%)\end{array}$ & $\begin{array}{c}\text { Growth } \\
\left(\mathbf{O D}_{\mathbf{6 0 0 n m}}\right)\end{array}$ \\
\hline $\mathbf{6 . 0}$ & 90.36 & 1.17 \\
$\mathbf{6 . 5}$ & 91.23 & 1.21 \\
$\mathbf{7 . 0}$ & 92.82 & 1.27 \\
$\mathbf{7 . 5}$ & 92.98 & 1.43 \\
$\mathbf{8 . 0}$ & 91.81 & 1.11 \\
\hline
\end{tabular}

Table.2 Variables and their levels employed in Plackett-Burman design for screening of some factors affecting phenol degradation by Candida tropicalis $\mathrm{H}$

\begin{tabular}{|c|c|c|c|c|}
\hline Symbol & Variable & $\begin{array}{c}\text { Low } \\
(-)\end{array}$ & $\begin{array}{l}\text { Basa } \\
1(0)\end{array}$ & $\begin{array}{c}\text { High } \\
(+)\end{array}$ \\
\hline A & $\mathrm{K}_{2} \mathrm{HPO}_{4}$ & 0.2 & 0.4 & 0.6 \\
\hline B & $\mathrm{KH}_{2} \mathrm{PO}_{4}$ & 0.2 & 0.4 & 0.6 \\
\hline $\mathrm{C}$ & $\mathrm{NaCl}$ & 0.05 & 0.1 & 0.15 \\
\hline $\mathrm{D}$ & $\mathrm{MgSO}_{4} \cdot \mathrm{H}_{2} \mathrm{O}$ & 0.1 & 0.2 & 0.3 \\
\hline $\mathrm{E}$ & $\mathrm{MnSO}_{4} \cdot \mathrm{H}_{2} \mathrm{O}$ & 0.005 & 0.01 & 0.015 \\
\hline $\mathrm{F}$ & $\mathrm{Fe}_{2}\left(\mathrm{SO}_{4}\right)_{3} \cdot \mathrm{H}_{2} \mathrm{O}$ & 0.005 & 0.01 & 0.015 \\
\hline G & $\mathrm{Na}_{2} \mathrm{MoO}_{4} \cdot 2 \mathrm{H}_{2} \mathrm{O}$ & 0.005 & 0.01 & 0.015 \\
\hline $\mathrm{H}$ & $\left(\mathrm{NH}_{4}\right)_{2} \mathrm{SO}_{4}$ & 0.5 & 1 & 1.5 \\
\hline I & pH & 7 & 7.5 & 8 \\
\hline $\mathrm{J}$ & Inoculum size (\%) & 3 & 5 & 7 \\
\hline $\mathrm{K}$ & Culture volume (ml) & 25 & 50 & 75 \\
\hline
\end{tabular}


Table.3 Randomized Plackett-Burman experimental design for evaluating factors influencing phenol degradation by Candida tropicalis $\mathrm{H}$

\begin{tabular}{|c|c|c|c|c|c|c|c|c|c|c|c|c|c|}
\hline $\begin{array}{l}\text { Variable } \\
\text { Trial }\end{array}$ & $\mathrm{A}$ & B & $\mathrm{C}$ & $\mathrm{D}$ & $E$ & $\mathrm{~F}$ & $\mathrm{G}$ & $\mathrm{H}$ & I & $\mathrm{J}$ & $\mathrm{K}$ & $\begin{array}{c}\text { Phenol } \\
\text { degrada - } \\
\text { tion }(\%)\end{array}$ & $\begin{array}{l}\text { Growth } \\
\left.\text { OD }_{600 \mathrm{~nm}}\right)\end{array}$ \\
\hline 1 & + & - & + & - & - & - & + & + & + & - & + & 93.55 & 1.52 \\
\hline 2 & + & + & - & + & - & - & - & + & + & + & - & 67.26 & 0.81 \\
\hline 3 & - & + & + & - & + & - & - & - & + & + & + & 71.72 & 1.24 \\
\hline 4 & + & - & + & + & - & + & - & - & - & + & + & 99.91 & 1.89 \\
\hline 5 & + & + & - & + & + & - & + & - & - & - & + & 93.80 & 1.53 \\
\hline 6 & + & + & + & - & + & + & - & + & - & - & - & 72.52 & 0.85 \\
\hline 7 & - & + & + & + & - & + & + & - & + & - & - & 58.08 & 0.78 \\
\hline 8 & - & - & + & + & + & - & + & + & - & + & - & 38.52 & 0.77 \\
\hline 9 & - & - & - & + & + & + & - & + & + & - & + & 71.76 & 1.26 \\
\hline 10 & + & - & - & - & + & + & + & - & + & + & - & 63.23 & 0.88 \\
\hline 11 & - & + & - & - & - & + & + & + & - & + & + & 72.74 & 1.36 \\
\hline 12 & - & - & - & - & - & - & - & - & - & - & - & 38.02 & 0.64 \\
\hline 13 & 0 & 0 & 0 & 0 & 0 & 0 & 0 & 0 & 0 & 0 & 0 & 92.89 & 1.04 \\
\hline
\end{tabular}

Table.4 Main effect and t-test of variables affecting phenol degradation by Candida tropicalis $\mathrm{H}$

\begin{tabular}{ccc}
\hline Factors & Main effect & t-test \\
\hline A & & $\mathbf{2 . 4 8}$ \\
& $\mathbf{2 3 . 2 3}$ & \\
B & 5.18 & 0.44 \\
C & 4.58 & 0.38 \\
D & 2.92 & 0.24 \\
E & -3.00 & -0.25 \\
F & 5.89 & 0.50 \\
G & -0.21 & -0.01 \\
H & -1.40 & -0.11 \\
I & 1.68 & 0.14 \\
J & -2.39 & -0.20 \\
K & 27.47 & 3.42 \\
\hline
\end{tabular}


Table.5 The influence of irrigation with treated and untreated phenol supplemented MSM on the growth of Triticum aestivum (monocot plant) and Lens culinaris (dicot plant)

\begin{tabular}{|c|c|c|c|c|c|c|}
\hline Test plant & \multicolumn{3}{|c|}{ Triticum aestivum } & \multicolumn{3}{|c|}{ Lens culinaris } \\
\hline $\begin{array}{c}\text { Growth } \\
\text { parameter }\end{array}$ & \multirow[t]{2}{*}{$\begin{array}{l}\text { Shoot } \\
\text { length } \\
(\mathrm{cm})\end{array}$} & \multirow[t]{2}{*}{$\begin{array}{l}\text { Root length } \\
(\mathrm{cm})\end{array}$} & \multirow[t]{2}{*}{$\begin{array}{c}\text { Dry } \\
\text { weight }(g)\end{array}$} & \multirow[t]{2}{*}{$\begin{array}{l}\text { Shoot } \\
\text { length } \\
(\mathrm{cm})\end{array}$} & \multirow[t]{2}{*}{$\begin{array}{l}\text { Root length } \\
\text { (cm) }\end{array}$} & \multirow[t]{2}{*}{$\begin{array}{c}\text { Dry } \\
\text { weight }(\mathrm{g})\end{array}$} \\
\hline $\begin{array}{l}\text { Irrigation } \\
\text { with }\end{array}$ & & & & & & \\
\hline $\begin{array}{c}\text { MSM } \\
\text { (control) }\end{array}$ & 13.1 & 14.2 & 0.19 & 13.8 & 10.2 & 0.29 \\
\hline $\begin{array}{l}\text { Treated } \\
\text { MSM }\end{array}$ & 12.5 & 13.3 & 0.18 & 12.2 & 8.1 & 0.25 \\
\hline $\begin{array}{l}\text { Untreated } \\
\text { MSM }\end{array}$ & \multicolumn{6}{|c|}{ No germination of both plants } \\
\hline
\end{tabular}

Fig.1 Phylogenetic relationships among representative experimental yeast isolate and the most related strains of Candida tropicalis

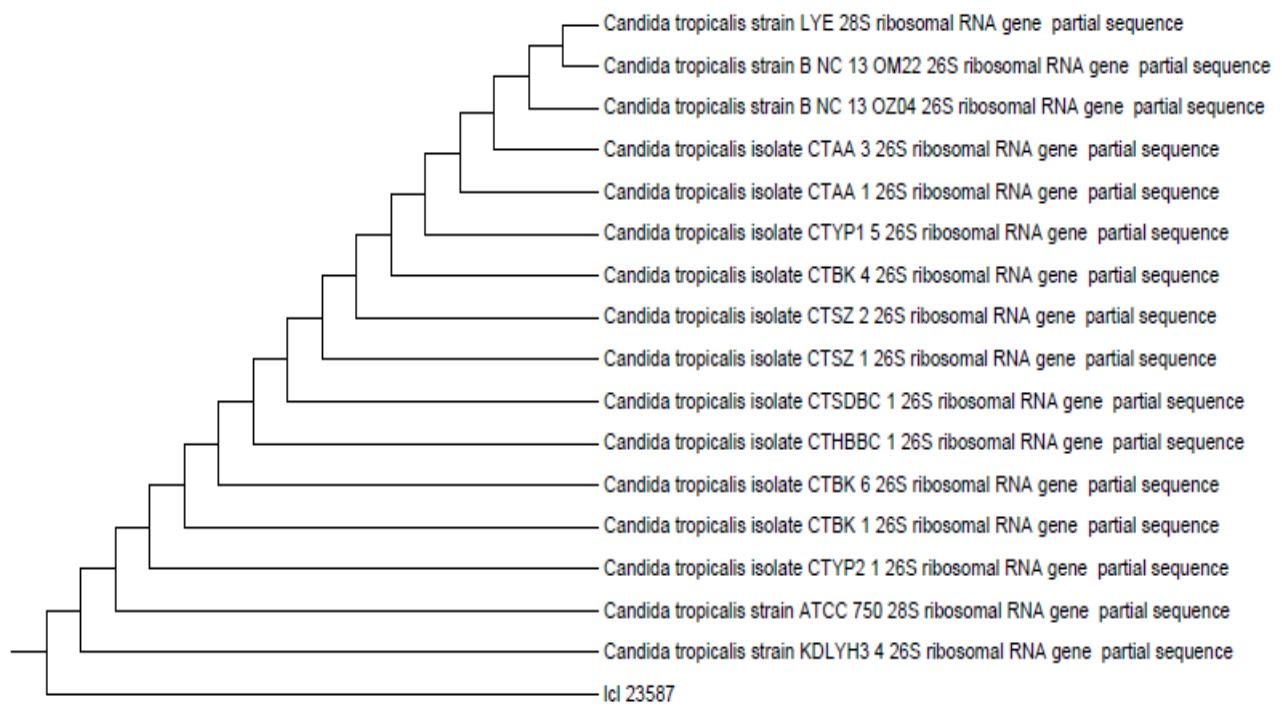

Fig.2 Effect of cultivation conditions on growth and phenol degradation by Candida tropicalis $\mathrm{H}$




Fig.3 Effect of incubation temperature on growth and phenol degradation by Candida tropicalis $\mathrm{H}$

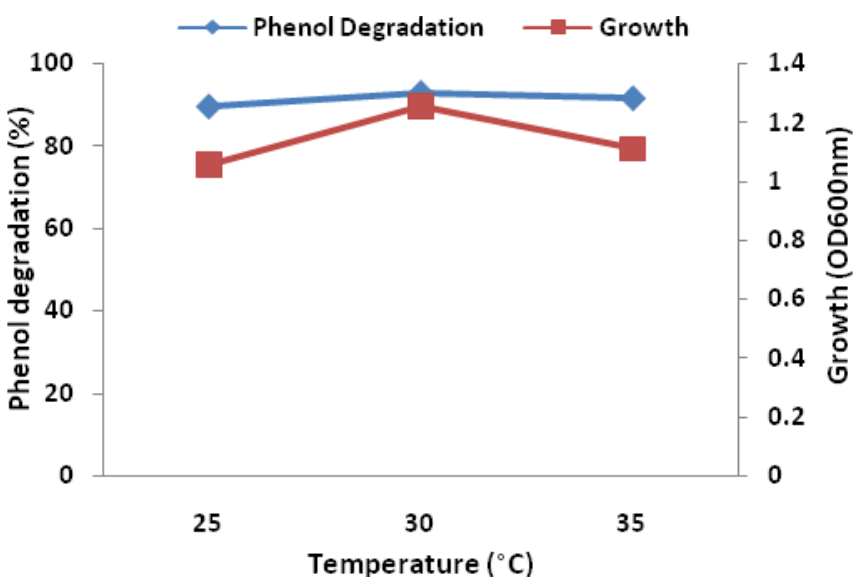

Fig.4 Effect of initial phenol concentration and incubation period on phenol degradation by Candida tropicalis $\mathrm{H}$

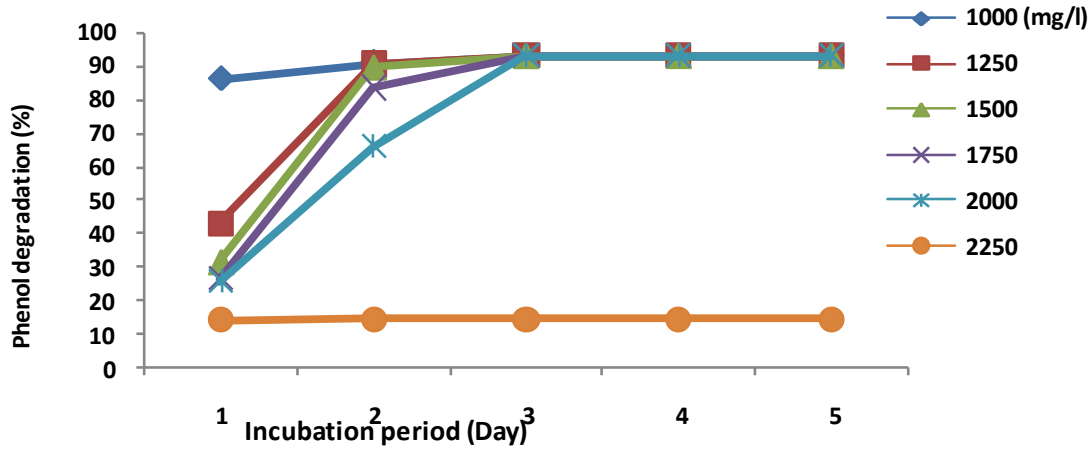

Fig.5 Main effect of variables affecting phenol degradation by Candida tropicalis $\mathrm{H}$

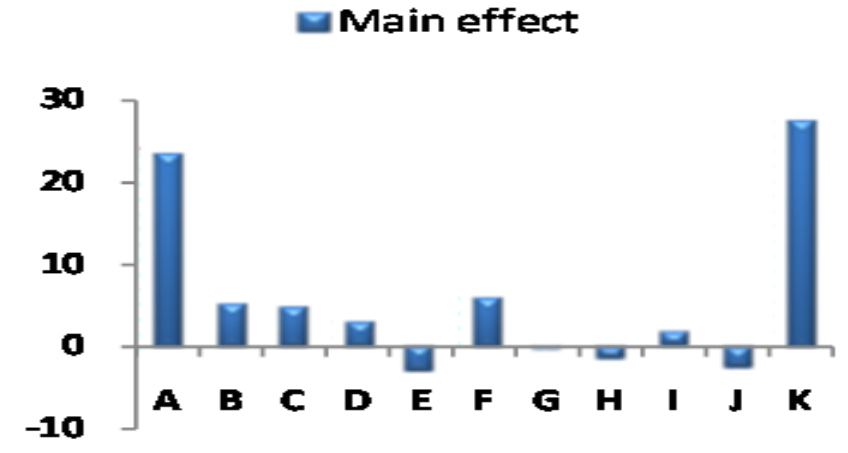


Fig.6 Effect of K2HPO4 and volume of the culture medium on phenol degradation by Candida tropicalis $\mathrm{H}$

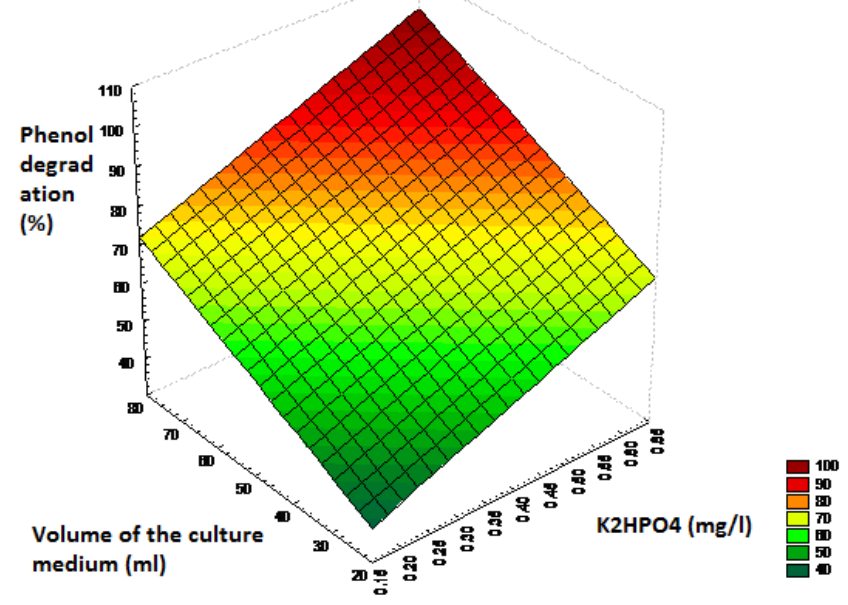

Fig.7 Time course degradation of phenol by Candida tropicalis $\mathrm{H}$ under optimized conditions



Time course degradation of phenol under optimized conditions

Time course degradation of phenol under optimized conditions was investigated to monitor the daily degradation process. The growth and percentage of phenol degradation by Candida tropicalis $\mathrm{H}$ were recorded (Fig. 7). The data showed that an incubation period shorter than 3 days was not enough to eliminate the concentration of phenol under investigation.

\section{Phytotoxicity study}

The influence of irrigation with treated and untreated phenol supplemented MSM on the growth of Triticum aestivum and Lens culinaris was demonstrated in table 5. Both plants failed to germinate when irrigated with untreated phenol supplemented MSM (2000 $\mathrm{mg} / \mathrm{l})$. However, they grew well when irrigated with treated phenol supplemented MSM by Candida tropicalis $\mathrm{H}$ and reached their maximum growth after 7 days. The growth of plants was compared with the 
control, which were the plants irrigated with MSM. Dry weights determined were in accordance with the observable plant growth (shoot and root lengths).

Phenol-containing effluents are known to cause environmental and health hazards and they are discharged in the natural water sources like rivers, unfortunately used to irrigate plants. Thus, assessing the phytotoxicity of the treated and the untreated phenol containing media was an important concern. In the present study, the results were found to be in accordance with the findings of Wolski et al., (2012), who proved that the degraded phenol $(400 \mathrm{mg} / \mathrm{l})$ by the fungal strain Penicillium chrysogenum Thom ERK1 was not toxic for the germination and growth of wheat.

In the present study concluded that the isolated yeast Candida tropicalis $\mathrm{H}$ was able to degrade (after optimization of the nutritional and environmental factors affecting phenol degradation process) 99.91 $\%$ of $2000 \mathrm{mg} / \mathrm{l}$ phenol in MSM (pH 7.5), within 3 days at $30{ }^{\circ} \mathrm{C}$ under shaken condition (100 rpm). A phytotoxicity study revealed that biodegradation of phenol by $C$. tropicalis $\mathrm{H}$ resulted in its detoxification. Therefore, phenol containing industrial and municipal effluents can be treated using $C$. tropicalis $\mathrm{H}$ in order to be used in the irrigation of nonedible plants.

\section{References}

Annadurai, G., Juang, R.S., Lee, D.J. 2002. Microbiological degradation of phenol using mixed liquors of Pseudomonas putida and activated sludge. Waste Manage J. 22, 703-710.

Aoyama, H., Hojo, H., Takahashi, K.L., Shimizu, N., Araki, M., Harigae, M., Tanaka, N., Shirasaka, N., Kuwahara, M., Nakashima, N., Yamamoto, E., Saka, M., Teramoto, S. 2005. A two-generation reproductive toxicity study of 2,4dichlorophenol in rats. J Toxicol Sci. 30, 59-78.

Arutchelvan, V., Kanakasabai, V., Elangovan, R., Nagarajan, S., Muralikrishnan, V. 2006. Kinetics of high strength phenol degradation using Bacillus brevis. $J$ Hazard Mater. 129, 216-222.

Banerjee, A., Ghoshal, A.K. 2010. Phenol degradation by Bacillus cereus: pathway and kinetic modeling. Bioresource Technol J. 101, 5501-5507.

Basak, B., Bhunia, B., Dutta, S., Dey, A. 2013. Enhanced biodegradation of 4chlorophenol by Candida tropicalis PHB5 via optimization of physicochemical parameters using Taguchiorthogonal array approach. Int Biodeterior J .78, 17-23.

Basha, K.M., Rajendran, A., Thangavelu, V. 2010. Recent advances in the biodegradation of phenol: a review. Asian J Exp Biol Sci. 1, 219-234.

Christen, P., Vega, A., Casalot, L., Simon, G., Auria, R. 2012. Kinetics of aerobic phenol biodegradation by the acidophilic and hyperthermophilic archaeon Sulfolobus solfataricus 98/2. Biochem Eng J . 62, 56-61.

El-Ashtoukhy, S.Z., El-Taweel, Y.A., Abdelwahab, O., Nassef, E.M. 2006. Treatment of petrochemical wastewater containing phenolic compounds by electrocoagulation using a fixed bed electrochemical reactor. Environ Toxicol Chem J. 25, 2455-2460.

EPA (Environmnetal protection Agency). Toxicological review of phenol 2002; from:

http://www.epa.gov/iris/toxreviews/0088t r.pdf.

Farag, A.M., Abd-Elnab, H.M. 2014. Degradation of phenol by a newdegradable marine halophilic fungus Fennellia flavipes isolated from Mangrove sediments. Life Sci J. 11, 836845.

Flocco, C.G., Lo Balbo, A., Carranza, M.P., Giulietti, A.M. 2002. Removal of phenol 
by alfalfa plants (Medicago sativa L.) grown in hydroponics and its effect on some physiological parameters. Acta Biotechnol J. 22, 43-54.

Geng, A., Soh, A.E., Lim, C.J., Loke, L.C. 2006. Isolation and characterization of a phenol-degrading bacterium from an industrial activated sludge. Appl Microbiol Biotechnol J. 71, 728-735.

Ghanem, K.M., Al-Garni, S.M., Al-Shehri, A.N. 2009. Statistical optimization of cultural conditions by response surface methodology for phenol degradation by a novel Aspergillus flavus isolate. Afr $J$ Biotechnol. 8, 3576-3583.

Hansch, C., McKarns, S.C., Smith, C.J., Doolittle, D.J. 2000. Comparative QSAR evidence for a free-radical mechanism of phenol-induced toxicity. Chem Biol Interact J. 127, 61-72.

Heipiper, H.J., Kewelo, H., Rehm, H.J. 1991. Influence of phenols on growth and membrane permeability of free and immobilized Esherishia coli. Appl Environ Microbiol J. 57, 1213-1217.

Heipieper, H.J., Diefebach, R., Kewelo, H. 1992. Conversion of cis unsaturated fatty acids to trans, a possible mechanism for the protection of phenol-degrading Pseudomonas putida P8 from substrate toxicity. Appl Environ microbial J. 58, 1847-1852.

Heipieper, H.J., Weber, F.J., Sikkema, J., Kewelo, H., de Bont, J.A.M. 1994. Mechanism of resistance of whole cells to toxic organic solvents. Chem Biol Interact J. 12, $409-415$.

Jiang, Y., Wen, J., Bai, J., Jia, X., Hu, Z. 2007a. Biodegradation of phenol at high initial concentration by Alcaligenes faecalis. Hazard Mater J. 147, 672 - 676.

Jiang, Y., Wen, J., Lan, L., Hu, Z. 2007b. Biodegradation of phenol and 4chlorophenol by the yeast Candida tropicalis. Biodegrad J. 18, 719-729.

Jung, J., Ishida, K., Nishihara, T. 2004. Antiestrogenic activity of fifty chemicals evaluated by in vitro assays. Life Sci J. 74, 3065-3074.
Keweloh, H., Weyrauch, G., Rehm, H.J. 1990. Phenol induced membrane changes in free and immobilized Esherichia coli. Appl Microbiol biotechnol J. 33, 65-71

Khanahmadzadeh, S., Khorshidi, N., Rabbani, M., Khezri, B. 2012. Removal of phenol in aqueous solutions by silica aerogel activated carbon nanocomposite. Appl Environ Biol Sci J . 2, 281-286.

Kim, J.W., Armstrong, N.E. 1981. A Comprehensive study on the biological treatabilities of phenol and methanol-II the effects of temperature, $\mathrm{pH}$, salinity and nutrients. Water Res J. 15, 12331247.

Krug, M., Straube, G. 1986. Degradation of phenolic compounds by the yeast Candida tropicalis HP 15.II. Some properties of the first two enzymes of the degradation pathway. Basic Microbiol J. 26, 271-281.

Kulkarni, S., Kaware, J. 2013. Adsorption for phenol removal- a review. IJSER. 1, 8896.

Kuntiya, A., Takenaka, S., Seesuriyachan, P. 2013. High potential of thermotolerant Candida tropicalis no. 10 for high concentration of phenol biodegradation. FABJ. 1, 59-68.

Liu, H., Yu, Q.J., Wang, G., Ye, F., Cong, Y. 2011. Biodegradation of phenol at high concentration by a novel yeast Trichosporon montevideense PHE1. Process Biochem J. 46, 1678 - 1681.

Liu, J., Wang, Q., Yan, J., Qin, X., Li, L., Xu, W., Subramaniam, R., Bajpai, R.K. 2013. Isolation and characterization of a novel phenol degrading bacterial strain WUSTC1. Ind Eng Chem Res J. 52, 258-265.

Martin, R.W. 1949. Rapid colorimetric estimation of phenol. Anal Chem J. 21, 1419-1420.

McCue, J.M., Lazis, S., Cohen, J.J., Modiano, J.F., Freed, B.M. 2003. Hydroquinone and catechol interfere with $\mathrm{T}$ cell cycle entry and progression through the G1 phase. Mol Immunol J. 9, 995-1001.

Michałowicz, J., Duda, W. 2007. Phenols sources and toxicity. PJoES. 16, 347-362. 
Neumann, G., Teras, R., Monson, L., Kivisaar, M., Frieder, S., Heipieper, H. 2004. Simultaneous degradation of atrazine and phenol by Pseudomonas sp. strain ADP: effects of toxicity and adaptation. Appl Environ Microbiol J. 70, 1907-1912.

Pakuła, A., Bieszkiewicz, E., BoszczykMaleszak, H., Mycielski, R. 1999. Biodegradation of phenol by bacterial strains from petroleum-refining wastewater purification plant. Pol $J$ Microbiol. 48, 373-380.

Pandimadevi, M., Venkatesh Prabhu, M., Vinod Kumar, V. 2014. Optimization of phenol degradation using Pseudomonas aeruginosa (MTCC 7814) by PlackettBurman design and response surface methodology. Bioremed Biodegrad J. 5, 261. doi: 10.4172/2155-6199.1000261.

Qadeer, R., Rehan, A.H. 2002. A study of the adsorption of phenol by activated carbon from aqueous solutions. Turk J Chem. 26, 357-361.

Robertson, B.K., Alexander, M. 1992. Influence of calcium, iron, and $\mathrm{pH}$ on phosphate availability for microbial mineralization of organic chemicals. Appl Environ Microbiol J. 58, 38-41.

Saeed, M., Ilyas, M. 2012. Oxidative removal of phenol from water catalyzed by nickel hydroxide. Appl Catal B J. 129, 247-254.

Schie, P.M., Young, L.Y. 1998. Isolation and characterization of phenol-degrading denitrifying bacteria. Appl Environ Microbiol J. 64, 2432-2438.

Sinha, P.K., Halder, S., Das, M. 2011. Phenol biodegradation and its recent advances: a review. Asian J Exp Biol Sci. 2, 119-134.

Sivasubramanian, S., Namasivayam, S.K. 2014. Optimization of parameters for phenol degradation using immobilized Candida tropicalis SSK01 in batch reactor. $J$ Environ Biol. 35, 531-536.

Soudi, M.R., Kolahchi, N. 2011. Bioremediation potential of a phenol degrading bacterium, Rhodococcus erythropolis SKO-1. P Bio Sci J. 1, 3140.

Supriya, M.C., Neehar, D. 2014. Biodegradation of phenol by Aspergillus niger IOSR. J Pharm. 4, 11-17.

Tiwari, S.K., Mondal, M.K. 2015. Biodegradation of phenol by Candida tropicalis NCIM 3118: equilibrium and rate studies. IJCEE. 6, 22-26.

Yao, G., Hou, Y. 2004. Nonylphenol induces thymocyte apoptosis through Fas/FasL pathway by mimicking estrogen in vivo. Environ Toxicol Pharmacol J. 17, 19-27.

Ucisik, A.S., Trapp, S. 2006. Uptake, removal, accumulation, and phytotoxicity of phenol in willow trees (Salix viminalis). Environ Toxicol Chem J. 25, 2455-2460.

Wolski, E.A., Barrera, V., Castellari, C., Gonzales, J.F. 2012. Biodegradation of phenol in static cultures by Penicillium chrysogenum ERK1: catalytic abilities and residual phytotoxicity. Rev Argent Microbiol J. 44, 113-121.

\section{How to cite this article:}

Hiba Koubeissi, Hoda Yusef and Hanafy Holail. 2017. Evaluation of Nutritional and Environmental Conditions for Phenol Degradation by a Lebanese strain of Candida tropicalis. Int.J.Curr.Microbiol.App.Sci. 6(2): 1386-1398. doi: http://dx.doi.org/10.20546/ijcmas.2017.602.157 